\title{
PARTISIPASI MASYARAKAT DALAM MEMBAYAR PAJAK BUMI DAN BANGUNAN (PBB) DI KELURAHAN KARANGPANIMBAL KECAMATAN PURWAHARJA KOTA BANJAR
}

\author{
Mira Andriani \\ mirayasjayawiharna@gmail.com \\ Dosen Sekolah Tinggi Ilmu Sosial dan Ilmu Politik \\ (STISIP) Bina Putera Banjar
}

\begin{abstract}
Abstrak
Berdasarkan hasil observasi ditemukan bahwa masih terdapat wajib pajak yang belum membayar pajak, sementara itu data yang didapat peneliti dari Kantor Kelurahan bahwa pelunasan Pajak Bumi dan Bangunan (PBB) sudah tercapai target.

Adapun penelitian ini menggunakan pendekatan kualitatif deskriptif. Data dikumpulkan melalui wawancara mendalam dari informan yang telah ditentukan dan dilakukan secara terus menerus sampai datanya jenuh.

Hasil penelitian menunjukkan bahwa Partisipasi Masyarakat Dalam Membayar Pajak Bumi dan Bangunan di Kelurahan Karangpanimbal Kecamatan Purwaharja Kota Banjar belum optimal. Diantaranya dapat dipengaruhi oleh faktor ekonomi dan juga terdapat tanah guntai. Keterlibatan wajib pajak untuk aktif membayar pajakpun masih lemah, disebabkan oleh tidak adanya sanksi tegas dari Pemerintah Kelurahan bagi yang belum maupun terlambat membayar pajak
\end{abstract}

Kata Kunci: Partisipasi, Wajib Pajak, Pajak Bumi dan Bangunan (PBB)

\section{Abstract}

Based on observations found that there are still taxpayers who have not paid taxes, while the data obtained by researchers from the Village Office that the settlement of Pajak Bumi dan Bangunan (PBB) has reached the target.

The research uses descriptive qualitative approach. Data were collected through in-depth interviews of informants that had been determined and carried out continuously until the data was saturated.

The results showed that the Community Participation in Paying Land and Building Tax in Karangpanimbal Sub-District Purwaharja District Banjar City has not been optimal. Among them can be influenced by economic factors and there is also a land of thunder. Taxpayers' involvement to actively pay taxes is still weak, due to the absence of strict sanctions from the Village Government for those who have not yet paid the tax

Keywords: participation, tax payers, Pajak Bumi dan Bangunan (PBB) 


\section{Pendahuluan}

Negara Kesatuan Republik Indonesia merupakan negara berkembang yang ada di Asia Tenggara yang saat ini Indonesia sebagai Negara pengimpor minyak, maka sumber utama penerimaan Negara bergeser dari penerimaan Migas menjadi penerimaan pajak. Karena penerimaan pajak selalu diupayakan untuk ditingkatkan.

Pajak secara umum dapat diartikan sebagai iuran atau pungutan yang dilakukan oleh pemerintah kepada masyarakat yang memiliki kewajiban membayar pajak yang lazim disebut dengan istilah Wajib Pajak (WP). Berdasarkan undang-undang dan hasilnya digunakan demi pembiayaan pengeluaran umum yang ditunjuk secara langsung. Pajak merupakan alat bagi pemerintah dalam mencapai satu tujuan yang dibebankan kepada masyarakat tanpa memberikan imbalan atau jasa.

Soemitro dalam Resmi (2008:1) mengemukakan bahwa

-Pajak adalah iuran rakyat kepada kas negara berdasarkan undang- undang (yang dapat dipaksakan) dengan tiada mendapat jasa timbal (kontraprestasi) secara langsung dapat ditunjukan dan yang digunakan untuk membayar pengeluaran umum .

Pajak diperuntukan untuk mensejahterakan masyarakat mendapatkan penerimaan baik yang bersifat langsung maupun tidak langsung dari masyarakat guna membiayai pengeluaran rutin serta pembangunan nasional dan ekonomi masyarakat. Sistem perpajakan selalu mengalami perubahan dari masa kemasa sesuai perkembangan masyarakat dan Negara, baik dalam bidang kenegaraan maupun dalam bidang sosial dan ekonomi.

Pemungutan pajak merupakan salah satu bentuk kegiatan yang terstruktur dan sistematis yang berkontribusi terhadap pendapatan negara. Pajak Bumi dan Bangunan (PBB) tidak dapat disangkal lagi telah memberikan keuntungan dan atau kedudukan sosial ekonomi yang lebih baik bagi orang atau badan yang mempunyai suatu hak atasnya atau memperoleh manfaat daripadanya, oleh karena itu wajar apabila mereka diwajibkan memberikan sebagian manfaat atau kenikmatan yang diperolehnya kepada negara berupa pembayaran pajak. Pajak merupakan kontribusi terbesar yang mengisi tampuk pendapatan negara. Hal ini sesuai dengan dasar hukum UU No. 28 Tahun 2009 bahwa: -Pajak daerah dan retribusi daerah merupakan salah satu sumber pendapatan daerah yang penting guna membiayai pelaksanaan pemerintahan daerah . 
Salah satu pembiayaan pelaksanaan kebijakan pemerintahan daerah tidak hanya dari satu pajak tertentu, namun ada satu pajak yang sangat erat kaitannya dengan sumber pendapat yang diperoleh dari daerah. Adapun pajak tersebut yaitu Pajak Bumi dan Bangunan (PBB). Pajak Bumi dan Bangunan (PBB) adalah pajak yang dipungut atas tanah dan bangunan karena adanya keuntungan dan/atau kedudukan sosial ekonomi yang lebih baik bagi orang atau badan yang memiliki hak kepemilikan atau mendapat manfaat atas keberadaan tanah dan bangunan tersebut.

Mekanisme pelunasan pajak di Daerah seperti di Kecamatan, pada awalnya diinformasikan melalui Surat Pemberitahuan Pajak Terutang yang selanjutnya disingkat menjadi Surat Pemberitahuan Pajak Pajak Terutang (SPPT) yang merupakan surat yang digunakan untuk memberitahukan besarnya nominal Pajak Bumi dan Bangunan (PBB) yang terutang kepada wajib pajak. Besarnya PBB yang terutang diperoleh dari perkalian tarif $(0,5 \%)$ dengan NJOP. Nilai Jual Kena Pajak ditetapkan sebesar $20 \%$ dari NJOP (jika NJOP kurang dari 1 miliar rupiah) atau 40\% dari NJOP (jika NJOP senilai 1 miliar rupiah atau lebih). Besaran pajak yang terutang dalam satu tahun pajak yang telah diinformasikan.

Mekanismenya sederhana yaitu setelah pajak diinformasikan kepada Wajib Pajak (WP) adalah orang pribadi atau badan yang memiliki hak dan/atau memperoleh manfaat atas tanah dan/atau memiliki, menguasai, dan/atau memperoleh manfaat atas bangunan. Wajib pajak memiliki kewajiban membayar pajak terutang setiap tahunnya. Pajak Bumi dan Bangunan (PBB) harus dilunasi paling lambat 6 (enam) bulan sejak tanggal diterimanya pajak terutang oleh wajib pajak. Pembayaran pajak dapat dilakukan melalui bank, melalui Anjungan Tunai Mandiri (ATM), atau melalui petugas pemungut dari pemerintah daerah, melalui kantor pos.

Jelasnya setelah sejak tanggal diterimanya Surat Pemberitahuan Pajak Terutang (SPPT) oleh wajib pajak pada bulan Februari, maka pelunasan paling lambat 6 bulan sejak diterimanya SPPT oleh Wajib Pajak (WP) yaitu jatuh pada bulan Juli.

Meskipun pemungutan pajak yang paling mudah mekanisme dan cara pelaksanaan pembayarannya, seperti yang diungkapkan di awal. Tetapi pada prakteknya ada satu sisi yang menjadi satu kondisi yang mengakibatkan pencapaian target menjadi kurang sesuai dengan harapan.

Berdasarkan hasil observasi awal peneliti menemukan beberapa permasalahan diantaranya sebagai berikut: 
1. Kurangnya kesadaran warga untuk membayar pajak bumi dan bangunan;

2. Tidak ada sangsi tegas bagi warga yang telat membayar pajak bahkan bagi yang menunggak;

3. Masih tingginya paradigma pemerintahan desa yang ingin pujian keberhasilan dalam pemerintahnya, sehingga mau menggunakan dana talang untuk menutupi wajib pajak yang menunggak yang justru hal tersebut tidak memberikan pelajaran atau penyelesaian masalah setiap tahunnya.

Sementara itu, berdasarkan data yang ada di Kantor Kelurahan Karangpanimbal Kecamatan Purwaharja Kota Banjar, untuk realisasi penyetoran pajak bumi dan bangunan di Kelurahan Karangpanimbal Kecamatan Purwaharja Kota Banjar disajikan dalam tabel 1.1.

Tabel 1.1

Rekapitulasi Pajak Bumi Dan Bangunan Perdesaan Dan Perkotaan Kota Banjar Buku 1, 2, 3 Transaksi Pembayaran 2017 Tahun Pajak 2017

\section{Kelurahan : Karangpanimbal \\ Kecamatan : Purwaharja}

\begin{tabular}{|c|l|c|r|r|r|}
\hline Kode & Uraian & $\begin{array}{c}\text { Tahun } \\
\text { SPPT }\end{array}$ & Pokok & Denda & \multicolumn{1}{c|}{ Jumlah } \\
\hline Februari & 091911: BJB & 2017 & 133.659 & 0 & 133.659 \\
\hline Maret & 091911: BJB & 2017 & 19.572 .405 & 0 & 19.572 .405 \\
\hline April & 091911: BJB & 2017 & 8.064 .780 & 0 & 8.064 .780 \\
\hline Mei & 091911: BJB & 2017 & 7.737 .267 & 0 & 7.737 .267 \\
\hline Juni & 091911: BJB & 2017 & 2.500 .122 & 0 & 2.500 .122 \\
\hline Juli & 091911: BJB & 2017 & 1.432 .560 & 0 & 1.432 .560 \\
\hline Agustus & 091911: BJB & 2017 & 3.959 .210 & 0 & 3.959 .210 \\
\hline September & 091911: BJB & 2017 & 10.979 .523 & 0 & 10.979 .523 \\
\hline \multicolumn{2}{|l}{} & Jumlah & 54.379 .526 & 0 & 54.379 .526 \\
\hline
\end{tabular}

Sumber: Kantor Kelurahan Karangpanimbal Kecamatan Purwaharja, 2017

Berdasarkan tabel di atas, merupakan kenyataan data yang sangat ironis sebab realisasi pelunasan Pajak Bumi dan Bangunan (PBB) di Kelurahan Karangpanimbal Kecamatan Purwaharja Kota Banjar telah tercapai dengan baik dan maksimal bahkan sesuai batas waktu yang telah ditetapkan oleh Pemerintah Kota Banjar yaitu pada bulan September.

Sehubungan adanya ketidaksesuaian antara kenyataan di lapangan dan data yang diperoleh dari Kelurahan, maka dari itu peneliti tertarik untuk melakukan penelitian 
lebih jauh mengenai hal tersebut dengan mengambil judul penelitian yaitu :

\section{“Partisipasi Masyarakat Dalam Membayar Pajak Bumi dan Bangunan (PBB) Di}

Kelurahan Karangpanimbal Kecamatan Purwaharja Kota Banjar".

Berdasarkan uraian masalah di atas, maka dari itu peneliti merumuskan masalahnya sebagai berikut: Bagaimanakah partisipasi masyarakat dalam membayar Pajak Bumi dan Bangunan (PBB) di Kelurahan Karangpanimbal Kecamatan Purwaharja Kota Banjar?

\section{Tinjauan Pustaka}

Kata partisipasi atau istilah partisipasi berasal dari bahasa latin, pars dan capere yakni -parscaparet yang berarti -mengambil bagian atau mengambil peran. Kemudian diserap menjadi bahasa Inggris yaitu participate yang memiliki pengertian

-keikutsertaan . Partisipasi juga merupakan sukarela dari masyarakat kepada proyek tanpa ikut serta dalam pengambilan keputusan serta keterlibatan sukarela oleh masyarakat dalam perubahan yang ditentukannya sendiri. Penggerak yang muncul dari seseorang/kelompok tidak akan muncul tanpa adanya rasa sadar diri dan tanggung jawab yang tinggi terhadap kepentingan bersama. Partisipasi uang merupakan bentuk partisipasi untuk memperlancar usaha-usaha bagi pencapaian kebutuhan masyarakat yang memerlukan bantuan.

Berkaitan dengan penelitian ini, maka diharapkan partisipasi masyarakat meningkat dalam membayar Pajak Bumi dan Bangunan. Dalam hal ini peneliti mengambil pendekatan teori partisipasi masyarakat disesuaikan dengan teori Mikkelsen (1999: 64) membagi partisipasi sebagai berikut:

1. Partisipasi adalah kontribusi sukarela dari masyarakat kepada proyek tanpa ikut serta dalam pengambilan keputusan;

2. Partisipasi adalah -pemekaan (membuat peka) pihak masyarakat untuk meningkatkan kemauan menerima dan kemampuan untuk menanggapi proyek-proyek pembangunan;

2 Partisipasi adalah keterlibatan sukarela oleh masyarakat dalam perubahan yang ditentukannya sendiri;

3 Partisipasi adalah suatu proses yang aktif, yang mengandung arti bahwa orang atau kelompok yang terkait, mengambil inisiatif dan menggunakan kebebasannya untuk melakukan hal itu;

4 Partisipasi adalah pemantapan dialog antara masyarakat setempat dengan para staf yang melakukan persiapan, pelaksanaan, monitoring proyek, agar supaya memperoleh informasi mengenai konteks lokal, dan dampak-dampak sosial;

5 Partisipasi adalah keterlibatan masyarakat dalam pembangunan diri, kehidupan, dan lingkungan mereka. 
Partisipasi bisa diartikan sebagai keterlibatan seseorang secara sadar ke dalam interaksi sosial dalam situasi tertentu. Dengan pengertian itu, seseorang bisa berpartisipasi bila ia menemukan dirinya dengan atau dalam kelompok, melalui berbagai proses berbagi dengan orang lain dalam hal nilai, tradisi, perasaan, kesetiaan, kepatuhan dan tanggungjawab bersama. Partisipasi masyarakat juga merupakan keikutsertaan masyarakat dalam proses pengidentifikasian masalah dan potensi yang ada di masyarakat, pemilihan dan pengambilan keputusan tentang alternatif solusi untuk menangani masalah, pelaksanaan upaya mengatasi masalah, dan keterlibatan masyarakat dalam proses mengevaluasi perubahan yang terjadi.

Pentingnya partisipasi sebagai berikut: pertama, partisipasi masyarakat merupakan suatu alat guna memperoleh informasi mengenai kondisi, kebutuhan, dan sikap masyarakat setempat, yang tanpa kehadirannya program pembangunan serta proyek-proyek akan gagal; kedua, bahwa masyarakat akan lebih mempercayai proyek atau program pembangunan jika merasa dilibatkan dalam proses persiapan dan perencanaannya, karena mereka akan lebih mengetahui seluk-beluk proyek tersebut dan akan mempunyai rasa memiliki terhadap proyek tersebut; ketiga, bahwa merupakan suatu hak demokrasi bila masyarakat dilibatkan dalam pembangunan masyarakat mereka sendiri.

\section{Metode Penelitian}

Penelitian ini berlokasi di Kelurahan Karangpanimbal Kecamatan Purwaharja Kota Banjar. Penelitian yang digunakan peneliti termasuk penelitian jenis deskriptif dengan pendekatan kualitatif, karena permasalahan yang ada masih bersifat sementara maka teori yang digunakan dalam penyusunan usulan penelitian masih bersifat sementara dan akan berkembang setelah penelitian dilapangan. Penelitian ini bertumpu pada latar belakang alamiah, memposisikan manusia sebagai alat penelitian, melakukan analisa data secara induktif dan lebih mementingkan proses daripada hasil.

Menurut Sugiyono (2013 : 9) Metode penelitian kualitatif adalah :

-Metode penelitian yang berlandaskan pada filsafat postpositivisme, digunakan untuk meneliti pada kondisi obyek yang alamiah, (sebagai lawannya adalah eksperimen) dimana peneliti adalah sebagai instrumen kunci, teknik pengumpulan data dilakukan secara triangulasi ((gabungan), analisis data bersifat induktif/kualitatif, dan hasil penelitian kualitatif lebih menekankan makna daripada generalisasi. 
Penelitian kualitatif merupakan strategi penelitian dimana di dalamnya peneliti menyelidiki suatu program, peristiwa, aktivitas, proses atau sekelompok individu. Kasus-kasus dibatasi oleh waktu dan aktivitas, dan peneliti mengumpulkan informasi secara lengkap dengan menggunakan berbagai prosedur pengumpulan data berdasarkan waktu yang telah ditentukan (Stake, 1995). Dalam penelitian ini yang akan diamati adalah Partisipasi Masyarakat Dalam Membayar Wajib Pajak Bumi Dan Bangunan (PBB) Di Kelurahan Karangpanimbal Kecamatan Purwaharja Kota Banjar. Dengan menggunakan metode kualitatif, maka data yang didapat akan lebih lengkap, lebih mendalam, Kredibel dan bermakna sehingga tujuan penelitian dapat dicapai. Dalam penelitian ini yang menjadi informan kunci adalah Lurah karena seorang Lurah adalah orang yang menduduki jabatan politik di Kelurahan sehingga akan memudahkan peneliti dalam melakukan penelitian dan menjelajahi situasi sosial yang diteliti.

Adapun teknik pengumpulan data dalam penelitian ini adalah melalui studi pustaka, observasi, wawancara dan teknik dokumentasi. Sedangkan untuk analisis data adalah menggunakan teknik analisis data dari Miles and Huberman (1984), yang mengemukakan bahwa aktifitas dalam analisis data kualitatif dilakukan secara interaktif dan berlangsung secara terus menerus sampai tuntas, sehingga datanya sudah jenuh. Aktifitas dalam analisis data, yaitu data reduction, data display, dan conclusion drawing/verification.

\section{Hasil Penelitian}

Dari hasil pelaksanaan penelitian mengenai partisipasi masyarakat dalam membayar Pajak Bumi dan Bangunan (PBB) di Kelurahan Karangpanimbal Kecamatan Purwaharja Kota Banjar, ditemukan beberapa jawaban informan sebagai berikut:

1) Partisipasi Masyarakat dalam Bentuk Kontribusi Sukarela dari Masyarakat

Kelurahan Karangpanimbal yang Menjadi Wajib Pajak Bumi dan Bangunan (PBB).

Dimensi kriteria partisipasi masyarakat dalam bentuk kontribusi sukarela dari masyarakat Kelurahan Karangpanimbal yang menjadi wajib pajak Pajak Bumi dan Bangunan (PBB). Pada pembayaran ini masyarakat dituntut untuk mampu membayar secara sukarela tanpa adanya unsur pemaksaan dari pihak pemungut wajib Pajak Bumi dan Bangunan (PBB), baik dalam proses ataupun praktik pembayaran, paksaan berupa pemungutan dengan jalan yang tidak sesuai dengan harapan masyarakat. Kontribusi 
sukarela ini dapat berupa kegiatan yang meringankan pemungut wajib Pajak Bumi dan Bangunan (PBB).

Pendapat mengenai bentuk kontribusi sukarela dari masyarakat Kelurahan Karangpanimbal masyarakat terhadap Pajak Bumi dan Bangunan dapat diketahui Partisipasi masyarakat membayar pajak Bumi dan Bangunan di Kelurahan Karangpanimbal sudah dianggap baik dan lancar.

Hal ini seperti yang dikemukakan oleh Herniaty Aisah, S.STP selaku Lurah Karangpanimbal, mengatakan:

Partisipasi masyarakat dalam membayar pajak Bumi dan Bangunan di Kelurahan Karangpanimbal sudah dianggap baik dan lancar, walaupun agak sedikit terlambat dalam membayar pajak Bumi dan Bangunan, namun bukan berarti tidak dapat melunasi, hanya terlambat membayar. Jika dihitung secara persentase sampai dengan bulan September waktu itu, maka 90 persenan lah target selesai sampai dengan bulan Agustus. (hasil wawancara dengan Herniaty Aisah, S.STP selaku Lurah Karangpanimbal, 03 Maret 2018).

Selanjutnya mengenai bentuk kontribusi sukarela dari masyarakat Kelurahan Karangpanimbal terhadap Pajak Bumi dan Bangunan tahun periode 2016-2017 dapat diketahui Wajib Pajak melaksanakan pembayaran ketika ada pungutan petugas, karena wajib pajak tidak bisa membayar di Kantor Pos, bank Bank Rakyat Indonesia, Bank Jabar Banten karena kendala prosedur yang memakan waktu lama dan tidak sederhana.

Hal ini seperti yang dikemukakan oleh Kasi Pemerintahan Kelurahan Karangpanimbal, mengatakan:

Wajib Pajak sudah sadar pajak, karena sudah membayar ketika ada pungutan oleh petugas, hanya secara membayar di tempat atau fasilitas yang telah disediakan misalnya di Bank atau Kantor Pos atau Tempat Pembayaran yang tercantum pada SPPT atau STTS. Dimana tempat tersebut antara lain Badan Kredit Kecamatan (BKK) yang berada di setiap Kecamatan, BCA, BUKOPIN, BNI, MANDIRI atau Kantor Pos, itu merupakan kontribusi sukarela yang tidak mungkin mengingat dari Kelurahan kami ke pusat Kecamatan hanya memakan waktu saja untuk mereka bekerja, namun sejauh ini, sebagian besar masyarakat Wajib Pajak harus menunggu penagihan dulu, baik RT atau petugas khusus dari Kelurahan. Wajib pajak baru akan membayar PBB. (hasil wawancara dengan Kasi Pemerintahan Kelurahan Karangpanimbal, 03 Maret 2018).

Selanjutnya mengenai bentuk kontribusi sukarela dari masyarakat Kelurahan Karangpanimbal masyarakat terhadap Pajak Bumi dan Bangunan (PBB) tahun periode 2016-2017 dapat diketahui bahwa partisipai masyarakat membayar Pajak Bumi dan 
Bangunan (PBB) kurang sukarela dijalankan dan akan dibayar setelah pemungut mendatangi wajib pajak.

Hal ini sesuai pendapat Jeni Irawan salah satu kolektor pajak, mengatakan:

Sebagai masyarakat yang dijadikan tokoh di sini, saya menilai partisipasi masyarakat dalam membayar PBB, kurang begitu sukarela, dalam pengertian begini, yang disebut sukarela itu, ketika slip SPPT dikasihkan ke wajib pajak saat itu juga harus dibayar, tapi sebagian masyarakat di sini ya begitulah, SPPT baru akan dibayar setelah pemungut ada datang ke rumah masingmasing wajib pajak. (hasil wawancara dengan Jeni Irawan salah satu kolektor pajak, 05 Maret 2018).

Berdasarkan beberapa pendapat mengenai bentuk kontribusi sukarela dari masyarakat Kelurahan Karangpanimbal terhadap Pajak Bumi dan Bangunan (PBB) tahun periode 2016-2017 di atas, maka dapat disimpulkan sementara, sebagai berikut bahwa Partisipasi masyarakat membayar pajak Bumi dan Bangunan di Kelurahan Karangpanimbal sudah dianggap baik dan lancar, walaupun agak terlambat melunasi Pajak Bumi dan Bangunan, dapat diketahui wajib Pajak melaksanakan pembayaran ketika ada pungutan petugas, karena wajib pajak tidak bisa membayar di kantor pos, bank Bank Rakyat Indonesia (BRI), Bank Jabar Banten (BJB) karena memakan waktunya untuk bekerja. Partisipasi masyarakat membayar Pajak Bumi dan Bangunan (PBB) kurang sukarela dijalankan dan akan dibayar setelah pemungut mendatangi wajib pajak.

2) Partisipasi Masyarakat Yang Bersifat Kepekakaan dalam membayar Pajak Bumi dan Bangunan (PBB)

Dimensi kriteria partisipasi masyarakat yang bersifat kepekakaan dalam membayar Pajak Bumi Dan Bangunan (PBB) yang dilaksanakan masyarakat Kelurahan Karangpanimbal yang menjadi wajib pajak Pajak Bumi dan Bangunan (PBB). Pada dimensi ini masyarakat dituntut untuk memiliki sifat peka tanpa adanya kegiatan sosialisasi apapun dari pihak pemungut wajib Pajak Bumi dan Bangunan (PBB), dari Pemerintahan Kelurahan Karangpanimbal.

Pendapat mengenai bentuk kepekaan masyarakat dalam membayar Pajak Bumi Dan Bangunan (PBB) di Kelurahan Karangpanimbal dapat diketahui bahwa kepekaan masyarakat yang menjadi wajib berada pada taraf yang peka terhadap 
pajak, karena semua wajib pajak atau masyarakat merasa menjadi warga negara yang baik yaitu harus membayar pajak.

Hal ini seperti yang dikemukakan oleh Herniaty Aisah, S.STP selaku Lurah Karangpanimbal, mengatakan:

Saya kira masyarakat atau warga Kelurahan Karangpanimbal yang menjadi wajib pajak Pajak Bumi dan Bangunan (PBB) sudah peka terhadap pajak, karena warga atau masyarakat bagian dari warga negara yang baik yaitu harus membayar pajak, karena bukan warga yang baik apabila tidak membayar pajak. (hasil wawancara dengan Herniaty Aisah, S.STP selaku Lurah Karangpanimbal, 03 Maret 2018).

Selanjutnya mengenai bentuk kepekaan masyarakat terhadap pembayaran Pajak Bumi Dan Bangunan (PBB) di Kelurahan Karangpanimbal dapat diketahui bahwa masyarakat sudah peka terhadap pajak, yang dibuktikan dengan pembayaran pajak, hal itu disebabkan ketepatan pembayaranya kurang tepat.

Hal ini seperti yang dikemukakan oleh Kasi Pemerintahan Kelurahan Karangpanimbal, mengatakan:

Sebagian besar masyarakat sudah peka terhadap pajak Bumi dan Bangunan (PBB), namun sebagian kecil masyarakat kurang peka, hal itu dibuktikan dengan sebagian kecil masyarakat dalam membayar pajak kurang tepat waktu. (hasil wawancara dengan Kasi Pemerintahan Kelurahan Karangpanimbal, 03 Maret 2018).

Selanjutnya mengenai bentuk kepekaan masyarakat terhadap pembayaran Pajak Bumi Dan Bangunan (PBB) di Kelurahan Karangpanimbal dapat diketahui bahwa masyarakat wajib pajak sudah peka terhadap pajak. Hal ini seperti yang dikemukakan oleh Ny. Suhartini sebagai salah satu wajib pajak, mengatakan bahwa -Perasaan saya sebagai wajib pajak selalu tepat membayar. Jadi perasaan saya sudah peka terhadap pajak, cuman saya bayar jika ada petugas RT yang memungut. (hasil wawancara dengan Ny. Suhartini sebagai salah satu wajib pajak, 05 Maret 2018).

Berdasarkan beberapa pendapat mengenai bentuk kepekaan masyarakat terhadap pembayaran Pajak Bumi dan Bangunan (PBB) di Kelurahan Karangpanimbal dapat diketahui bahwa masyarakat wajib pajak sudah peka terhadap Pajak Bumi dan Bangunan (PBB) tahun periode 2016-2017 di atas, maka dapat disimpulkan sementara bahwa kepekaan masyarakat Kelurahan 
Karangpanimbal yang menjadi wajib berada pada taraf yang peka terhadap pajak, karena semua wajib pajak atau masyarakat merasa menjadi warga negara yang baik yaitu harus membayar pajak. Ada sebagian kecil masyarakat kurang peka, hal itu dibuktikan dengan ketepatan pembayaran yang kurang tepat.

3) Partisipasi adalah keterlibatan sukarela oleh masyarakat dalam perubahan yang ditentukannya sendiri;

Dimensi kriteria partisipasi masyarakat dalam bentuk keterlibatan sukarela dari masyarakat Kelurahan Karangpanimbal yang menjadi wajib pajak Pajak Bumi dan Bangunan (PBB). Pada pembayaran ini masyarakat dituntut adanya keterlibatan sukarela tanpa adanya unsur pemaksaan dari pihak pemungut wajib Pajak Bumi dan Bangunan (PBB), baik dalam proses ataupun praktik pembayaran, paksaan berupa pemungutan dengan jalan yang tidak sesuai dengan harapan masyarakat. Pendapat mengenai bentuk keterlibatan sukarela dari masyarakat Kelurahan Karangpanimbal masyarakat terhadap Pajak Bumi dan Bangunan dapat diketahui Partisipasi masyarakat membayar pajak Bumi dan Bangunan di Kelurahan Karangpanimbal sudah dianggap baik dan lancar.

Hal ini seperti yang dikemukakan oleh Herniaty Aisah, S.STP selaku Lurah Karangpanimbal, mengatakan:

Keterlibatan sukarela masyarakat dalam membayar pajak Bumi dan Bangunan di Kelurahan Karangpanimbal sudah dianggap baik dan lancar, walaupun agak sedikit terlambat dalam membayar pajak Bumi dan Bangunan, namun bukan berarti tidak dapat melunasi, hanya terlambat membayar. Jika dihitung secara persentase sampai dengan bulan September waktu itu, maka 90 persenan lah target selesai sampai dengan bulan Agustus. (hasil wawancara dengan Herniaty Aisah, S.STP selaku Lurah Karangpanimbal, 03 Maret 2018).

Selanjutnya mengenai bentuk kontribusi sukarela dari masyarakat Kelurahan Karangpanimbal terhadap Pajak Bumi dan Bangunan tahun periode 2016-2017 dapat diketahui Wajib Pajak melaksanakan pembayaran ketika ada pungutan petugas, karena wajib pajak tidak bisa membayar di Kantor Pos, bank Bank Rakyat Indonesia, Bank Jabar Banten karena kendala prosedur yang memakan waktu lama dan tidak sederhana.

Selanjutnya mengenai bentuk keterlibatan sukarela dari masyarakat Kelurahan Karangpanimbal masyarakat terhadap Pajak Bumi dan Bangunan (PBB) 
tahun periode 2016-2017 dapat diketahui bahwa partisipai masyarakat membayar Pajak Bumi dan Bangunan (PBB) kurang.

Hal ini sesuai pendapat Jeni Irawan salah satu kolektor pajak, mengatakan: Partisipasi masyarakat dalam membayar PBB, kurang adanya keterlibatan sukarela, dalam pengertian begini, yang disebut sukarela itu, ketika slip SPPT dikasihkan ke wajib pajak saat itu juga harus dibayar, tapi sebagian masyarakat di sini ya begitulah, SPPT baru akan dibayar setelah pemungut ada datang ke rumah masing-masing wajib pajak, mereka tidak sukarela membayar di Kantor Pos, bank Bank Rakyat Indonesia, Bank Jabar Banten (hasil wawancara dengan NN salah satu kolektor pajak, 05 Maret 2018).

Berdasarkan beberapa pendapat mengenai bentuk keterlibatan sukarela dari masyarakat Kelurahan Karangpanimbal terhadap Pajak Bumi dan Bangunan (PBB) tahun periode 2016-2017 di atas, maka dapat disimpulkan sementara, sebagai berikut bahwa Partisipasi masyarakat membayar pajak Bumi dan Bangunan di Kelurahan Karangpanimbal sudah dianggap baik dan lancar, walaupun agak terlambat melunasi Pajak Bumi dan Bangunan, dapat diketahui wajib Pajak melaksanakan pembayaran ketika ada pungutan petugas, karena wajib pajak tidak bisa membayar di kantor pos, bank Bank Rakyat Indonesia (BRI), Bangk Jabar Banten (BJB) karena memakan waktunya untuk bekerja. Partisipasi masyarakat membayar Pajak Bumi dan Bangunan (PBB) kurang sukarela dijalankan dan akan dibayar setelah pemungut mendatangi wajib pajak.

4) Partisipasi Masyarakat Terlibat Secara Aktif dalam membayar Pajak Bumi dan Bangunan (PBB).

Dimensi keterlibatan masyarakat secara aktif dalam membayar Pajak Bumi dan Bangunan (PBB). Partisipasi masyarakat terlibat secara aktif tanpa adanya kegiatan sosialisasi apapun dari pihak pemungut wajib Pajak Bumi dan Bangunan (PBB) Kelurahan Karangpanimbal.

Pendapat mengenai keterlibatan masyarakat secara aktif dalam membayar Pajak Bumi dan Bangunan (PBB) di Kelurahan Karangpanimbal dapat diketahui bahwa masyarakat sudah aktif dalam membayar pajak. Hal ini seperti yang dikemukakan oleh Herniaty Aisah, S.STP selaku Lurah Karangpanimbal, mengatakan bahwa -Masyarakat di Kelurahan Karangpanimbal, saya rasa sudah 
aktif dalam membayar Pajak Bumi dan Bangunan (PBB). (hasil wawancara dengan Herniaty Aisah, S.STP selaku Lurah Karangpanimbal, 03 Maret 2018).

Selanjutnya mengenai keterlibatan masyarakat secara aktif dalam membayar Pajak Bumi dan Bangunan (PBB) di Kelurahan Karangpanimbal dapat diketahui bahwa warga bisa disebut aktif ataupun kurang aktif. Warga yang aktif membayar adalah warga yang asli sedangkan warga yang kurang aktif pemilik tanah guntai. Hal ini seperti yang dikemukakan oleh Ulung Sugandi salah satu kolektor pajak, mengatakan:

Warga di Kelurahan Karangpanimbal, bisa dibilang sudah aktif dalam membayar iuran SPPT, bisa juga dibilang kurang aktif. Yang aktifmah asli orang sini, yang ketika SPPTnya dikasihkan langsung dibayar, tetapi pemiliki tanahnya orang luar atau guntai menyulitkan pelunasan pajak tanah. (hasil wawancara dengan Ulung Sugandi salah satu kolektor pajak, 03 Maret 2018).

Selanjutnya mengenai keterlibatan masyarakat secara aktif dalam membayar Pajak Bumi dan Bangunan (PBB) di Kelurahan Karangpanimbal dapat diketahui bahwa pengakuan warga termasuk warga yang aktif membayar. Hal ini seperti yang dikemukakan oleh Uyan sebagai salah satu wajib pajak mengatakan bahwa -Kami sebagai wajib pajak perasaan saya selalu aktif dalam membayar pajak . (hasil wawancara dengan Uyan sebagai salah satu wajib pajak, 05 Maret 2018).

Berdasarkan beberapa pendapat mengenai keterlibatan masyarakat secara aktif dalam membayar Pajak Bumi dan Bangunan (PBB) di Kelurahan Karangpanimbal dapat disimpulkan sementara bahwa masyarakat di Kelurahan Karangpanimbal sudah aktif dalam membayar pajak. Warga bisa disebut aktif ataupun kurang aktif. Warga yang aktif membayar adalah warga yang asli sedangkan warga yang kurang aktif pemilik tanah guntai.

5) Partisipasi adalah pemantapan dialog antara masyarakat setempat dengan para staf yang melakukan persiapan, pelaksanaan, monitoring pembayaran Pajak Bumi dan Bangunan (PBB) di Kelurahan Karangpanimbal Kecamatan Purwaharja Kota Banjar.

Dimensi kriteria partisipasi masyarakat dalam pemantapan dialog antara masyarakat setempat dengan para staf yang melakukan persiapan, pelaksanaan, monitoring pembayaran Pajak Bumi dan Bangunan (PBB) di Kelurahan 
Karangpanimbal Kecamatan Purwaharja Kota Banjar. Pada pembayaran ini masyarakat dituntut adanya keterlibatan langsung pihak Pemerintahan Kelurahan Karangpanimbal dalam sosialisasi pembayaran Pajak Bumi dan Bangunan (PBB).

Hal ini seperti yang dikemukakan oleh Herniaty Aisah, S.STP selaku Lurah Karangpanimbal, mengatakan:

Keterlibatan pemerintahan Kelurahan Karangpanimbal dalam melakukan persiapan, pelaksanaan, monitoring pembayaran Pajak Bumi dan Bangunan (PBB) sudah baik dan lancer, pihak Kelurahanpun sering mengadakan rapatrapat yang dihadiri oleh RT/RW maupun kolektor pajak tentang arahanarahan dan pembinaan dalam pemungutan Pajak Bumi dan Bangunan (PBB) di Kelurahan Karangpanimbal (hasil wawancara dengan Herniaty Aisah, S.STP selaku Lurah Karangpanimbal, 03 Maret 2018).

Sementara itu, Jeni Irawan salah satu kolektor pajak membenarkan pernyataan Lurah Karangpanimbal meskipun sedikit perbedaannya dengan mengatakan bahwa: -Pernah kami rapat hanya satu kali pada saat pembagian SPPT yang harus disebarkan ke wajib pajak, itu saja (hasil wawancara dengan Jeni Irawan salah satu kolektor pajak, 05 Maret 2018).

Berdasarkan beberapa pendapat mengenai pemantapan dialog antara masyarakat setempat dengan para staf yang melakukan persiapan, pelaksanaan, monitoring pembayaran Pajak Bumi dan Bangunan (PBB) di Kelurahan Karangpanimbal Kecamatan Purwaharja Kota Banjar, maka dapat disimpulkan sementara kurang adanya keterlibatan Kelurahan dalam sosialisasi Pajak Bumi dan Bangunan (PBB) di Kelurahan Karangpanimbal Kecamatan Purwaharja Kota Banjar.

6) Partisipasi adalah keterlibatan masyarakat dalam pembangunan diri, kehidupan, dan lingkungan mereka untuk meningkatkan ketepatan membayar Pajak Bumi dan Bangunan (PBB) di Kelurahan Karangpanimbal Kecamatan Purwaharja Kota Banjar.

Dimensi kriteria partisipasi masyarakat dalam bentuk keterlibatan masyarakat dalam pembangunan diri, kehidupan, dan lingkungan mereka untuk meningkatkan ketepatan membayar Pajak Bumi dan Bangunan (PBB) di Kelurahan Karangpanimbal Kecamatan Purwaharja Kota Banjar. Pada pembayaran ini masyarakat dituntut menanamkan dalam dirinya rasa kewajiban untuk membayar Pajak Bumi dan Bangunan (PBB) dengan kesadaran yang tinggi dan upaya meningkatkan hasil usahanya setiap waktu agar pada saat pembayaran PBB tidak 
berbenturan dengan kebutuhan lain yang utama seperti untuk memenuhi kebutuhan makan.

Hal ini seperti yang dikemukakan oleh Herniaty Aisah, S.STP selaku Lurah Karangpanimbal, mengatakan:

Dalam hal ini masyarakat dituntut menanamkan dalam dirinya rasa kewajiban untuk membayar Pajak Bumi dan Bangunan (PBB) dengan keasdaran yang tinggi dan upaya meningkatkan hasil usahanya setiap waktu agar pada saat pembayaran PBB tidak berbenturan dengan kebutuhan lain yang utama seperti untuk memenuhi kebutuhan makan (hasil wawancara dengan Herniaty Aisah, S.STP selaku Lurah Karangpanimbal, 03 Maret 2018).

Hal ini sesuai pendapat Sono sebagai salah satu wajib pajak, mengatakan: Keterlibatan masyarakat dalam pembangunan diri, kehidupan, dan lingkungan mereka untuk meningkatkan ketepatan membayar Pajak Bumi dan Bangunan (PBB) tidak bisa dilakukan oleh masyarakat saja, hal ini tentunya harus ada upaya pemerintah Kelurahan dengan kebijakannya yang inopatif seperti pernah saya dengar di sebuah desa di Kota Banjar memiliki kebijakan dari Kepala Desa untuk menanam tanaman yang dapat menghasilkan dan menguntungkan di lahan umum sebagai upaya hasilnya dapat dijadikan warga untuk membayar PBB dan dirawat bersama.... Oh ya saya ingat itu Kebijakan -satu pohon satugu tapi lupa nama desanya. (hasil wawancara dengan Sono salah satu wajib pajak, 05 Maret 2018).

Berdasarkan beberapa pendapat mengenai bentuk pembangunan diri, kehidupan, dan lingkungan mereka untuk meningkatkan ketepatan membayar Pajak Bumi dan Bangunan (PBB) bahwa masyarakat dituntut menanamkan dalam dirinya rasa kewajiban untuk membayar Pajak Bumi dan Bangunan (PBB) dengan keasdaran yang tinggi dan upaya meningkatkan hasil usahanya setiap waktu agar pada saat pembayaran PBB tidak berbenturan dengan kebutuhan lain yang utama seperti untuk memenuhi kebutuhan makan. Namun, hal ini tidak bisa dilakukan oleh masyarakat saja, hal ini tentunya harus ada upaya pemerintah Kelurahan dengan kebijakannya yang inopatif.

\section{Penutup}

\section{Simpulan}

Berdasarkan hasil penelitian mengenai Partisipasi Masyarakat dalam membayar Pajak Bumi Dan Bangunan (PBB) Di Kelurahan Karangpanimbal 
Kecamatan Purwaharja Kota Banjar, maka dapat ditarik kesimpulan sebagai berikut: Bentuk Partisipasi Masyarakat dalam membayar Pajak Bumi Dan Bangunan (PBB) Di Kelurahan Karangpanimbal Kecamatan Purwaharja Kota Banjar tampak dari kesukarelaan membayar Pajak Bumi dan Bangunan (PBB) sudah cukup berpartisipasi. Sebagian besar masyarakat sudah memiliki kepekaan terhadap pelunasan Pajak Bumi dan Bangunan (PBB), namun sebagian kecil masih kurang peka terutama pemilik tanah guntai.

\section{Saran}

Berdasarkan kesimpulan di atas, maka peneliti perlu mengajukan beberapa saran sebagai berikut:

1. Dalam kegiatan sosialisasi Pajak Bumi dan Bangunan (PBB), hendaknya petugas atau perangkat Kelurahan dapat menyesuaikan waktu yang tepat kepada masyarakat dengan tidak menggangu aktivitas wajib pajak. Sehingga wajib pajak akan lebih nyaman untuk mengikuti sosialiasi tersebut. Dengan demikian wajib pajak akan memiliki pengetahuan tentang tujuan dan manfaat Pajak Bumi dan Bangunan (PBB). Sehingga masyarakat dapat kesukarelaan, peka, dan aktif dan berperan serta dalam melunasi pajak secara tepat.

2 Petugas atau perangkat Kelurahan berkaitan dengan Pajak Bumi dan Bangunan (PBB) hendaknya memberikan tugas khusus kepada setiap Rukun Tetangga (RT) mengenai pemungutan pajak, jika perlu gunakan surat tugas dari Lurah, hal ini menghindari rasa ketidakpercayaan wajib pajak terhadap Rukun Tetangga (RT) yang ditugasi.

3 Petugas atau perangkat Kelurahan berkaitan dengan Pajak Bumi dan Bangunan (PBB) hendaknya memberitahukan kepada wajib pajak mengenai sanksi Pajak Bumi dan Bangunan (PBB), bukan hanya waktu dan target untuk melunasi Pajak Bumi dan Bangunan (PBB). Sehingga Pajak Bumi dan Bangunan (PBB) dapat mengerti dan taat terhadap saksi yang diberikan. 


\section{DAFTAR PUSTAKA}

Hasibuan, H. 2003. Organisasi dan Motivasi. Jakarta. PT Bumi Aksara

Hasibuan S.P. Malayu. 1995. Manajemen Sumber Daya Manusia. Jakarta: Bumi Aksara

Imam Baihaqi Luqman. 2011. Skripsi berjudul: Analisis Faktor-faktor Penentu Kebijakan Pendaerahan PBB Sektor Perdesaan Dan Perkotaan. Fakultas Ilmu Sosial dan Ilmu Poltik Universitas Indonesia: Tidak diterbitkan.

Indah Kusuma Dewi 2012. Analisis Biaya Pemungutan PBB Sektor Pedesaan dan Perkotaan Setelah diserahkan ke Daerah. Fakultas Ilmu Sosial dan Ilmu Poltik Universitas Indonesia: Tidak diterbitkan.

Mangkunegara, Anwar Prabu.2005. Evaluasi Kinerja. Bandung: Refika Aditama

Mikkelsen. Britha. 2010. Metode Penelitian Partispatoris dan Upaya-Upaya Pemberdataan. Jakarta : Yayasan Obor Indonesia.

Mardiasmo. 2009. Perpajakan Edisi Revisi. Yogyakarta : C.V Andi Offset.

Moch. As‘ad, 1995. Psikologi Industri. Jakarta: Liberty.

Nafilah.2013.Intensifikasi Pemungutan Pajak Bumi dan Bangunan di Dinas Pendapatan Daerah Kota Makassar. Universitas Hasanudin Fakultas Ilmu Sosial Dan Ilmu Politik: Tidak diterbitkan.

Rati Meriani Nadeak.2014. Kesadaran dan Kepatuhan Wajib Pajak Dalam Membayar Pajak Bumi Dan Bangunan (PBB) Sektor Perkotaan (Studi di Kelurahan Tegal Sari Mandala II, Kecamatan Medan Denai). Fakultas Ilmu Sosial dan Ilmu Poltik Universitas Sumatera Utara Medan:Tidak diterbitkan.

Rivai, Veithzal. 2004. Manajemen Sumber Daya Manusia Untuk Perusahaan. Jakarta: PT. Rajagrafindo Persada.

Robbins dan Judge. 2007. Perilaku Organisasi, Buku 1 dan 2. Jakarta: Salemba Empat

Sardiman A.M. 2007. Interaksi dan motivasi belajar mengajar. Jakarta: Rajagrafindo Persada

Siagian, Sondang. P. 2008. Manajemen Sumber Daya Manusia. Jakarta: Bumi Aksara

Resmi. Siti 2010. Perpajakan, Teori dan Kasus. Buku I. Edisi II. Jakarta: Salemba

Sugiyono. 2011. Metode Penelitian Administratif (Pendekatan Kuantitatif, Kualitatif. Bandung: Alfabeta.

Surakhmad. 1985. Metode Penelitian Sosial. Jakarta: Ghalia Indonesia. 
Tim Penyusun Kamus.2008. Kamus Bahasa Indonesia. Jakarta: Pusat Perbukuan Nasional.

Waluyo, dan Wirawan B. Ilyas, 2010. Perpajakan Indonesia, Edisi Revisi, Salemba Empat, Jakarta.

Widodo, Atim Widodo, dan Andrea Hendro Puspita. 2010. Pajak Bumi dan Bangunan. Jakarta: Mitra Wacana Media. 